\title{
The Moravian heritage of community musicking
}

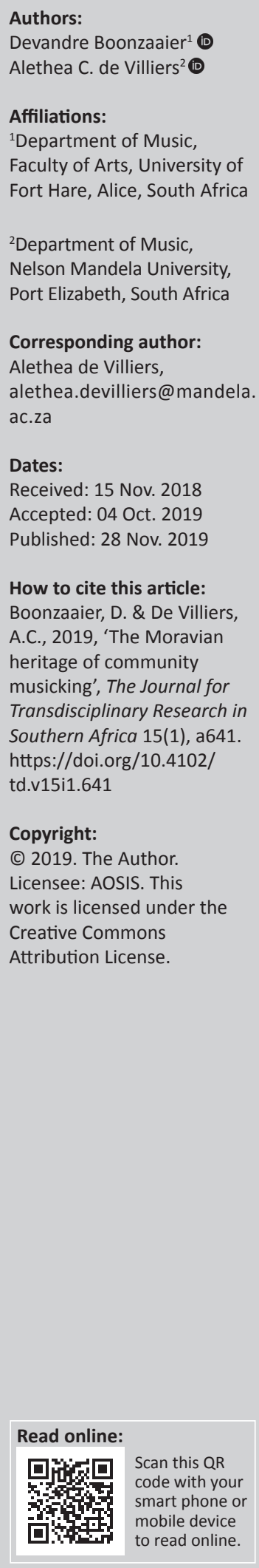

In this article, the authors firstly provide a brief historical narrative of the origin of the Moravian Church and its hymnody. Secondly, they proceed to trace the origins of Moravian hymnals and their use in South Africa. Thirdly, they discuss the history of Moravian hymnals in South Africa and the contribution of South African composers and musicians. Several articles and books were consulted to trace the contribution of the Moravian hymnal from its origins in Herrnhut in Germany to Genadendal, the first Moravian mission station in South Africa and the spread of the Moravian denomination to the rest of the country. The authors also provide short biographies of selected South African Moravian composers and highlight the connectedness of Moravians across time through their hymnody. Moreover, in this article the authors use the term, 'musicking' to describe the musical activity from composing to performing to listening-in-audience to singing.

Keywords: Moravian; heritage; community; musicking; South Africa; hymns.

\section{Introduction}

The Moravian Church is a traditional, Protestant church which promotes and maintains the legacy and practices of its founding fathers. For this reason, present day Moravian composers continue with the tradition of the early German composers. These music-related traditions include, (1) the compositional style, (2) easily singable tunes, (3) numbering of hymn tunes, (4) themes of the hymns and (5) scriptural texts of the hymns. By following this tradition, contemporary composers contribute to the heritage, legacy and unity of the Moravian Church. These musical practises ensure unity and continuity within the Christian worship from the inception of the Moravian Church to the present day. This also establishes a universal brotherhood and sisterhood among the worldwide congregation of Moravians, irrespective of culture or race.

\section{Moravian music heritage: A brief history}

The Moravian Church (Herrnhuter Brüdergemeine) grew under the leadership of Count Nikolaus Ludwig von Zinzendorf (1700-1760), out of the settlement of Herrnhut (Saxony), founded by Moravian exilees in 1722 (Traupman-Carr 2000:17). This church continued the tradition and orders of their ancestral church, the Unitas Fratrum (Church of the Bohemian brethren). Zinzendorf, a Lutheran of Pietist upbringing, created a unique and original Christ-centred worship tradition, emphasising experience, simplicity and community, which is reflected to varying degrees in the worship followed today in 19 provinces, but which remains the source of its distinctive common features (Bradshaw 2002:322).

\section{Moravian hymnody}

The Moravian hymn books currently in use today, have their origin in numerous collections of hymns spanning many centuries. Reed Knouse (2008:44) suggests that Moravian hymnody itself had already begun before the 16th century. According to Reed Knouse (2008), what has been hailed as the 'first Protestant hymnal' containing 89 hymns was printed in Prague in 1501. Reed Knouse (2008) further suggests that it has long been claimed as a hymnal of the Unitas Fratrum, but its connection with the Unitas Fratrum is tenuous, although it did contain 11 hymns by Lukas of Prague, the most influential theologian of the Unitas Fratrum.

Weinlick and Frank (2010:34) write that the brethren of the Unitas Fratrum memorised and could recite the hymns as they did with the scripture. According to Weinlick and Frank (2010), a characteristic of the Unitas Fratrum was its singing tradition, which was established long before the first Protestant hymnal of 1501. The Unitas Fratrum relied on hymns for both inspiration and 
teaching. During the next 70 years, 10 different editions of their hymnals were published, five in Czech, three in German and two in Polish (Weinlick \& Frank 2010).

The brethren composed hundreds of hymns and published the first hymnal in 1505. Some of these hymns became part of general Protestant worship during the Reformation (Settari 1994:5). In addition, some of the hymns of the Moravians date back to the ancient Christian Church of the 4 th century. These Moravian hymns provide more than just a moment for congregational singing; the Moravian hymns often express the Moravian faith better than any creedal statement (Fries 2003:44).

Fries (2003) states that although new styles of music and contemporary hymns have been introduced in Moravian churches, many of the hymns date back to Bishop Christian Gregor's 1784 tune book. Christian Gregor (1723-1801) is regarded by Moravians as the father of Moravian music. $\mathrm{He}$ is perhaps the most central figure, apart from Zinzendorf, in the development of the musical heritage of the Moravians. He has also been called 'the first outstanding musical personality in the Renewed Moravian church' (Reed Knouse 2008:18).

J.D. Grimm (1719-1760) and Christian Gregor (1723-1801) established the practice, still used by Moravians today, of arranging and numbering the tunes according to the length of the tunes. This enables more than one tune to be used for a hymn (August 2001:ii).

Weinlick (2001:85) points out that during the time of Zinzendorf hymnbooks were seldom used, except by visitors, because Count Zinzendorf was of the conviction that a hymn must be memorised to express the individual's Christian experience adequately. To this day, Moravians often sing hymns from memory, especially if they grew up in the tradition of having attended a Moravian school and grew up on a Moravian mission station. Moreover, Zinzendorf's hymns are still sung today, centuries later, in over 90 languages, including Afrikaans (Lewis 1962:168).

\section{The Moravian music tradition in South Africa}

The origin of the Moravian Church in South Africa can be traced back to the establishment of a Christian community, by Georg Schmidt, in Genadendal, in the Cape, in the 18th century. The adoption of distinct religious teachings and cultural (including musical) practices characterised this early Christian congregation. The English translation of Genadendal is 'Vale of Grace' and is the first mission station in South Africa (De Wet, Teugels \& Van Deventer 2014:94; Gordon 1927:96).

In 1832, the community in Genadendal welcomed its first organ, which was first played by the missionaries who then later taught a young person from the community so that he could be the church organist. Of further importance for the promotion of church music in South Africa, was the establishment of a seminary in Genadendal in 1838. The first director, Francke was a gifted musician who established church choirs first in Genadendal and then at Mamre, another mission station, also in the Western Cape (Jooste 1992:157). The seminary enabled the Moravians to train both priests and teachers, which ensured that in the Moravian schools all teachers, male and female, were members of the church. They made good use of the daily religious instruction periods, using a guide that was edited by the Provincial Board and revised several times (Krüger \& Schaberg 1984:132-133). From 1875 to 1883, most Moravian congregations in South Africa, began to have more autonomy and became more independent from Germany and began to establish a rich liturgical heritage, which provided many opportunities for singing and music performances.

\section{Moravian hymnody in South Africa}

The first Dutch hymnal of the Moravian Church was published in 1773 in Zeist, Netherlands, and was brought to Cape Town by missionaries in 1792 (Reichelt \& De Schweinitz 1886). The Lutheran congregation in Strand Street, Cape Town, started using the 1826 Netherlands Lutheran Hymnal in 1830 to replace the German hymnal of the Dom Church of Bremen which had been in use since 1783 (Laudate 1983:iv). In 1844, the Rhenish Missionary Society published a hymnal in the Dutch language for its congregations in South Africa and the Berlin Missionary Society followed suit in 1853. This hymnal and the other hymnals each had their own style and influenced the development of congregational songs and the religious songs in South Africa (Laudate 1983:iv).

The Dutch hymnal dating back to 1773 , was re-edited at Genadendal for the first time in 1880 and contained 800 hymns. In addition, many liturgies and litanies as well as the special services for Passion Week and other festive times throughout the church year gave the congregations the opportunity to participate actively in worship. Hallbeck's booklet Litanijen en Gezangen of 1839 was also still in use. The South African helpers entered this tradition with their remarkable musical talents and took the lead (Krüger \& Schaberg 1984:12).

Over time, the need for an Afrikaans hymnal was prompted with Afrikaans being used as the vernacular in churches. It was difficult for many congregants to abandon the Dutch hymnals. The first Afrikaans hymnal, Cantate, by the Berlin Missionary Society, was the work of Rev. J. Baumbach and the hymnal was published in 1934. From 1935, work commenced on an Afrikaans hymnal for the Moravian Church in South Africa which was first printed in 1949 and compiled by Rev. W. Winckler. It was replaced in 1959 by an enhanced edition under the editorial guidance of Bishop P.W. Schaberg. The Rhenish congregations in South-West Africa used the Sionsgesange (1947) of the Dutch Reformed Missionary Church. This hymnal was a work of the Rhenish missionary Rev. E. Hartwig. In 1962, a special edition of the 
Moravian Church hymnal known as Jubilate came into use. The German congregations of the United Evangelic-Lutheran Church in Southern Africa progressively started using the Cantate hymnal for their church services (Laudate 1983:iv).

The need for a communal hymnal was identified. The goal was that the content and language of the new hymnal would be an improvement on all previous hymnals and it would build on the foundation that was laid by the pioneers. The executive committee of the Federation of Evangelic-Lutheran Churches in Southern Africa in 1975 commissioned its Committee on Liturgy and Church Music to compile a communal hymnal. The committee consulted existing hymnals of the churches involved; especially, the rich treasure of the Evangelic hymns of Martin Luther and Paul Gerhardt and their contemporaries. They also consulted the old and renewed hymns of the Moravian Church and specifically the hymns of Zinzendorf and his fellow workers. In the selection of the hymns of the sister Protestant churches in South Africa, the Moravians received co-operation from the reformed churches in South Africa and the Dutch Reformed Church publishers. Many hymns were also translated into Afrikaans and English (Laudate 1983:iv-v).

The tunes were numbered in a similar way to the style of the first Moravian books according to length; numbers up to tune 236 were retained (Laudate 1983:xi-xii). The South African Moravian hymnal was published in Genadendal in 1983 (Laudate 1983). The hymns in the hymnal are arranged according to the following categories, (1) church calendar, (2) the church service, (3) praise and prayer hymns for all seasons, (4) hymns for special occasions and (5) hymns for eternity. The hymns in the Church Year Calendar category are divided into the following subcategories: Advent, Christmas, New Year, Epiphany, Lent, Easter, Ascension, Pentecost and Trinity. The hymns of the church service category include Sunday and Church Srvice, God's Word, Holy Baptism, Confirmation and Holy Communion. The subcategories under the category praise and prayer hymns include praise, thanksgiving, and worship; prayer; church, congregation, community; extension of the word; repent and conversion; Christian faith; God's trust and comfort; Jesus' love; charity. The hymns for special occasions include hymns for the morning, afternoon and evening; daily bread, occupation and work; marriage, home and family. The hymns for the eternity category in the hymnal are divided into the following subcategories: farewell and death; pilgrimage, coming of the Lord; long for heaven; and new life from now to eternity. The hymns in the hymnal are further divided into three sections: (1) hymn 1-479 in Afrikaans, (2) hymn 501759 also in Afrikaans and (3) the English hymns from hymn 801 until hymns 839. Hymns 1-479 form the communal hymnal of the Federation of Evangelical Lutheran Churches in South Africa (FELCSA). Hymns that could not be included in the general hymnal were added to the Moravian hymnal with the numbering of the hymns starting at number 501 and arranged according to the same themes as hymns $1-479$. The Moravian hymnal also added 40 English hymns numbered
800-839 (Laudate 1983). While the numbering may seem peculiar, this is how it appears in the hymnal.

The Chorale Book of the Moravian Church in South Africa was prepared to meet the need of having the tunes used in the South African Province of the Moravian Church collected in a single volume (August 2001:i). Previously, hymns were contained in the first printed tune book, Koraalboek van die Broederkerk (the Green Book published in 1964 for the Jubilate hymnal) and a hymnal, The Laudate, which was published in 1983 at a time of ecumenical co-operation within the erstwhile FELCSA. This mutual effort, unfortunately, left the Moravian Church in South Africa without a comprehensive tune or choral book, with the result that the Moravian Church in South Africa had to make use of several tune books. These included Die Koraalboek van die Broederkerk, 'The Choral book for the Australian Lutheran Hymnal' and that of the Evangelisches Kirchen Gesangbuch (August 2001).

The colour of the choral book is blue, hence its name: The Blue Tune Book. The previous choral book was green. This Blue Tune Book, also known as Choral Book of the Moravian Church in South Africa, replaced and combined the content of the aforementioned chorale books to indicate all the tunes composed and arranged for the hymns in the Laudate hymnal (L) in section B (designated by ' $\mathrm{W}$ '), as well as for the popular English hymns in section $\mathrm{C}$ (designated by ' $\mathrm{T}$ '). For the final arrangements of the tunes, use has been made of the Choralbuch der Evangelischen Brüdergemeine (Lonas 1890). Some tunes are recent variations by indigenous composers (cf. D.Z.L. Apolles; C. Hans senior; D. Joorst; D. Ulster and E.J. Williams) while others were taken from the Koraalboek vir Psalms en Gesange ( 1978) and the Choral Book of the Lutheran Church in South West Africa (August 2001:i-ii). The register of the authors appears in the Laudate hymnal on pages 731753; the register of sources in Laudate, page 754 and a list of melodies from pages 757-765 in the Laudate hymnal. The sources that were consulted for the compilation of the English hymns are:

- The Moravian Hymn Book and Liturgy, 1960 from the British Province of the Moravian Church.

- Hymnal and Liturgies of the Moravian Church, 1969 from the American Province of the Moravian Church.

Grimm and Gregor's method was utilised to arrange the melodies (August 2001:ii). After the Laudate was published, the Moravian Church Board of South Africa appointed Rev. K. Th. August as the coordinator for church music and entrusted him with the task of appointing a commission to revise the tune book. Then, he with the assistance of the late J.C. (Hansie) Petersen, compiled a first working draft in 1989. A commission comprising Messrs (the late) Pat Johannes, Tyrone Hitzeroth, the late Albert Engel and Ivan Liedeman from the Brass Band Association of South Africa (BBSA), as well as the late Christopher Hans, Jonathan and Antonio Lawack and Christo van der Rheede from the Moravian Church Choir Union of South Africa (MOCUSA), was formed with Rev. August as the convenor and editor in 1997. 
After the late Pat Johannes printed a revised draft, copies were sent to the BBSA and the MOCUSA members of the commission who gave input. These texts were all integrated by Christo van der Rheede, who did extensive transcription and typesetting on the computer. The final product was printed at the Genadendal Printing press (August 2001:ii).

The discussion so far reveals that the history of Moravian hymnals is intertwined with the traditions of the related Protestant denominations and the history and heritage of the Moravian Church. Furthermore, the Moravian hymnals in use in South Africa today, including the Laudate, are part of the heritage of modern day South African musicians and composers in so far as they have contributed to the compilation and composition of tunes for congregational worship.

\section{Heritage and contemporary Moravian hymn composers}

Meskell (2012:49) writes that heritage in South Africa has been called upon to fulfil numerous state-level agendas: on the domestic front, it is to provide social and economic regeneration as well as identity politics for nation-building. According to Meskell (2012) on the international front, national heritage needs to connect to the rest of the continent, to constitute a precise Africanity, to contribute to the narrative of origins and achievements that underpin the African Renaissance and to fulfil globalists' fantasies of self-sustainability.

In this article, heritage will specifically refer to the tangible and intangible cultural heritage of the South African Moravians:

Where history is the study of the past, heritage is the many ways the past is used in the present. In this way, heritage can be understood to be an active, dynamic relationship between then and now, formed through an on-going process of renegotiation, reconstruction, and recreation of what we choose to take from the past with us into the future. (University of Cambridge, n.d. n.p.)

Weinlick and Frank (2010:111) suggest that church members of any denomination have a certain religious profile derived not just from their own immediate Christian experience but also from the experience of their ancestors. According to them (Weinlick \& Frank 2010), this is the reason why denominations are often referred to as 'traditions'. Consequently, the Moravian composers' music can be viewed as practice, tradition and heritage.

Moreover, the authors will use the term, 'musicking' as coined by Small (1998). 'Musicking' is a verb that is inclusive of different musical activities, including composing, performing, listening-in-audience as well as singing (BoyceTillman 2016:3-4).

\section{Moravian Church music as a community}

The 'idea of community is at the heart of Biblical theology' (Kunhiyop 2012:9). Robinson (2014:14) quotes Allen (1966) when she states that the essence of Moravian belief can be found in their motto, 'in essentials unity, in non-essentials liberty; in all things charity'. The Moravians believed that musical ability, like every other gift, was to be used in praise of Christ and for the good of the community, not for the benefit of the individual (Reed Knouse 2008:19). Moreover, Hall (1981:226) states that the focus of Moravian theology can be found in music making. Hall (1981:227) furthermore points out that the singing of hymns and chorales formed part of the school music. The Singstunde, a song session was included in every school day. In this way, the school children came to know the church's religious beliefs and experienced musical training through the singing of hymns.

As Caldwell (2007:9) explains, a Moravian congregation, or Gemeine, encompassed all aspects of life, including schools and music. Children growing up in the Gemeine would be educated in its schools by teachers who were Moravians and be given the skills necessary to participate in the Gemeinmusik as singers in the congregation or choir, or as instrumentalists both as children and as adults, whatever their station in life. Gemeinmusik, encompassing the congregation's total repertoire of hymn-singing, liturgical singing, instrumental and sacred vocal music, was both a body of music and a program of music making that represented the Moravian faith in the unity of the sacred and secular, and the oneness of the performer and the listener within the local community or congregation. Gemeinmusik embraced ever-widening circles from local communities to the worldwide community of Moravian churches, and to the transcendental communion of saints on the earth and in heaven.

Pickel (1997:32) writes that identity formation always involves a struggle between the individual and his or her self-perception, and the categorisation of the individual through others. In other words, he (Pickel 1997) states that identity formation is a result of multiple forms of social interaction. He furthermore also points out that although individuals receive sets of information, roles, values and so forth, and become members of a family as well as the wider community, they retain the opportunity to reject the dominant in-group as well as out-group beliefs, habits, existing prejudices, stereotypes and social categorisations (Pickel 1997). The composers under discussion in this article, and by implication to their music, reflect their adoption of the Moravian identity through many forms of social interaction, both at school and in the church.

The idea of the church as a community resonates very well with Africans (Kunhiyop 2012:145). Although we are all born as individuals, we grow up and live within communities (Kunhiyop 2012). None live entirely by themselves. For Africans, one could even say that existence is meaningless without the concept of community, as is highlighted by the common sayings 'I am because we are, and since we are, therefore I am' and 'I am because we are related' (Kunhiyop 2012).

Kunhiyop (2012:145) moreover expands on Pickel's (1997) notion of social interaction by stating that the community is where you get your values and beliefs and your early training 
in life; the community is also where you establish the deepest and most enduring relationships in life. Morgan and BoyceTillman (2016:5) write that community arts activity is not new and the church choir is perhaps one of the oldest examples of this.

Your community is the group of people from whom you derive your name and your identity as a person. In the community, you find a sense of purpose in life because you realise that you can help make it better. Ife (2013:182) writes that good community development will bring people together and ensure that all community activities can enhance community-building, by seeking to involve people as much as possible, to increase their mutual dependence for the accomplishment of tasks and to provide opportunities for both formal and informal interaction. Similarly, the church is a community, and the Moravian Church specifically, as are the different organisations associated with it such as the Moravian BBSA and the MOCUSA that are integral to the Moravian community, where members are initiated into a community of practice. Both BBSA and MOCUSA are unions within the Moravian Church in South Africa having a distinct uniform which can be regarded as a sign of cultural unity among its members. It is also within these groups that people develop their identity as Moravians and a sense of belonging to a community of church musicians, connected to all other Moravians. It is within this Moravian community, where individuals derive their name as a Christian and their identity as a child of God (Kunhiyop 2012:145).

Zinzendorf was clear that it is very difficult to be ethical without a community, whether it is at the congregational level or in smaller groups, such as bands and choirs (Freeman 1998:235). Community makes possible the practice of a Christian life that would be difficult otherwise. Freeman (1998) writes that community consists of all those who join around the crucified Saviour or who share a relationship of the heart with the Saviour; however, community is also with the 'family' of God: father, son and mother. Freeman (1998) maintains that though many of the Moravians were involved in extended journeys and in continuous contacts with societies all over the world, behind their endeavours there was always the community to which they could return, and the mystical community in which they shared wherever they were.

Weinlick and Frank's (2010) study describes what The Ground of the Unity, ${ }^{1}$ states about the church as a community of service, in point 8 as stated below:

Jesus Christ came not to be served but to serve. From this, His Church receives its mission and its power for its service, to which each of its members is called. We believe that the Lord has called us particularly to mission service among the peoples of the world. In this, and in all other forms of service both at home and abroad, to which the Lord commits us, He expects us to confess Him and witness to His love in unselfish service. (pp. 123-127)

1.The Ground of the Unity is a Moravian statement of faith approved at the General (Unity) Synod of 1957.

\section{Moravian hymnody as a community}

Akrofi, Smit and Thorsén (2007:181) maintain that hymnody forms an essential part of the religious language and (self-) expression of most believers within the Christian religion. According to Akrofi et al. (2007) although most believers would seldom recognise it as such, hymns are not only about religious and theological expression. They (Akrofi et al. 2007) believe that hymnody also forms an important part of the cultural identities, frames of (world) interpretation, ideologies, self-concepts, symbols, moral values and the collective cultural memory of believers or Christians within a nation, which means that Christians within all nations have certain hymnic and hymnological identities. Akrofi et al. (2007:182) cite Kück and Kurzke (2003) by stating that hymns are symbols and cultural identities of churches and nations. In the context of this article, it is to be noted that the aforegoing descriptions of Moravian hymnody revealed that they conform to specific conventions.

To expand on the thesis of Moravian as a community, the authors of this article, will use two hymns by way of illustration. These two Moravian hymns are part of the worldwide Moravian Church, including South Africa. These are hymn 833 and hymn 834 (Laudate 1983). These hymns reflect history and heritage in the Moravian community, that include the conventions of numbering hymns, established by Grimm and Gregor.

Laudate, hymn 833, a hymn of Christian Love, was composed by Nicolas Ludwig von Zinzendorf (1700-1769) in German and the text was translated into English by Frederick William Foster (1760-1835). The text of the hymn is provided below:

1. Christian hearts, in love united, seek alone in Jesus rest; has He not your love excited? Then let love inspire each breast. Members on our Head depending lights reflecting Him, our Sun, Christians, His commands attending, we in Him, our Lord, are one.

2. Come, then, come, $\mathrm{O}$ flock of Jesus, covenant with Him anew; unto Him who conquered for us, pledge we love and service true; and should our love's union holy firmly linked no more remain, wait ye at His footstool lowly, till He draw it close again.

3. Grant, Lord, that with Thy direction, 'Love each other', we comply. Aiming with unfeigned affection Thy love to exemplify, let our mutual love be glowing, so that all will plainly see that we, as on one stem growing, living branches are in Thee.

4. O that such may be our union as Thine with the Father is, 
and not one of our communion e'er forsake the path of bliss;

may our light shine forth with brightness,

from Thy light reflected, shine;

thus the world will bear us witness,

that we, Lord, are truly Thine. (Laudate Dominum 833)

Nicolas Ludwig von Zinzendorf (1700-1760) was born in Dresden and raised by his grandmother, Countess von Gersdorf. He received his education at the Halle Paedogogium from 1710 to 1716 and later proceeded to study law at Wittenberg. In 1722, he gave permission for exilees from Moravia to settle on his estate at Berthelsdorf. Over time, he came to identify more and more with these exilees and in 1727 formulated the 'Brotherly Agreement' to create unity and to reconcile differences among them. In 1735, he was ordained a Lutheran minister and was consecrated a bishop of the renewed Moravian Church in 1737. Zinzendorf visited Moravian communities around the world. He was a prolific scholar, authoring numerous texts, including sermons, Bible commentaries and many hymns. It can be said that Zinzendorf established the theology of the 18th century Moravian Church (Reed Knouse 2008:287).

Frederick William Foster (1760-1835), an Englishman, was the second son of William Foster. Frederick Foster was born at Bradford. He was educated at Fulneck, which is close to Leeds in England. He also attended educational institutions in Europe, in Barby in Prussian Saxony and held many positions in the Moravian Church. In 1818, he was consecrated a bishop of the Moravian Church. He is renowned for his compilation of the Moravian Hymn Book of 1801, its supplement of 1808 and the revised edition of 1826 . He translated texts from the original German into English and composed original hymns that appear in this collection (Hymnary.org, n.d.).

Daniel Ulster (1926-1986) was born in Clarkson, a Moravian station in the Eastern Cape, and was the son of the Moravian minister, Rev. H.S. Ulster and brother of the Moravian Bishop, Rt. Rev. Ulster. He first studied medicine at the University of Cape Town, but later changed courses to study for his Bachelor of Music degree. Daniel Ulster qualified as a teacher and lectured at Battswood College and succeeded Dr. R.E. van der Ross as principal. He was the principal of Bellville College until his passing. Furthermore, he served as an organist and choir leader at Wynberg Moravian Church and conducted the Spes Bona Choir and orchestra in Cape Town (E. Williams pers. comm., 25 June 2014). The South African Moravian composer, Dan Ulster, composed a tune, Tune 167 $\mathrm{f}$ (see Figure 1), for hymn 833, based on the original text of Zinzendorf. The original tune composed by Zinzendorf can be found in Figure 2.

Christian hearts, in love united:

seek alone in Jesus rest;

has He not your love excited?

Then let love inspire each breast.

Members on our Head depending lights reflecting Him, our Sun,

Christians, His commands attending,

we in Him, our Lord, are one. (Laudate Dominum 833)

Laudate, hymn 834, was written by Ludolf Ernst Schlicht and is sung to tune 39. The South African composer, Jonathan Lawack, composed a tune for hymn 834:

1. What brought us together, what joined our hearts? The pardon which Jesus, our High Priest, imparts; 'Tis this which cements the disciples of Christ, who are into one by the Spirit baptised.

2. Is this our high calling, harmonious to dwell, and thus in sweet concert Christ's praises to tell, in peace and blessed union our moments to spend and live in communion with Jesus our Friend?

3. O yes, having found in the Lord our delight, he is our chief object by day and by night; this knits us together; no longer we roam; we all have one Father, and heav'n is our home. (Laudate Dominum 834)

Ludolf Ernst Schlicht (1714-1769) attended the theological seminary at Jena and arrived in Herrnhut in 1738, where he served using his musical gifts primarily for the young. He was officially inducted into the Moravian Church in 1739. He was the accompanist for worship and composed many anthems, cantatas as well as hymn texts. In 1742, he was ordained and served in several congregations in both England and Ireland. It is most likely that Schlicht was the editor of the 1746 English Moravian hymnal. In 1753, he was called to Bedford, England, where he translated the hymnal into English and the liturgy book into English (Reed Knouse 2008:282). Following, is the hymn as composed by Schlicht.

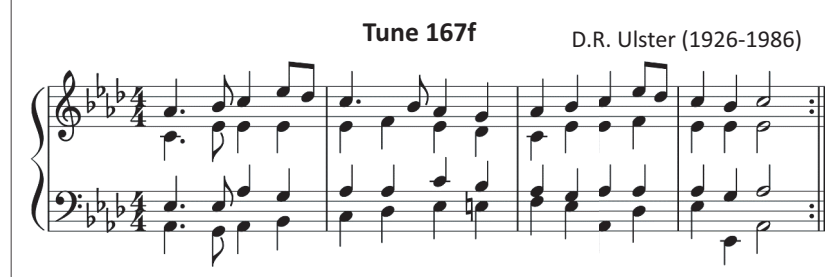

5

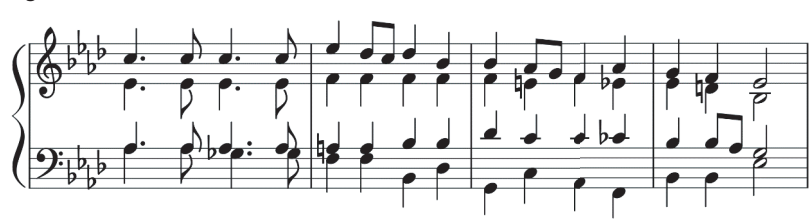

9

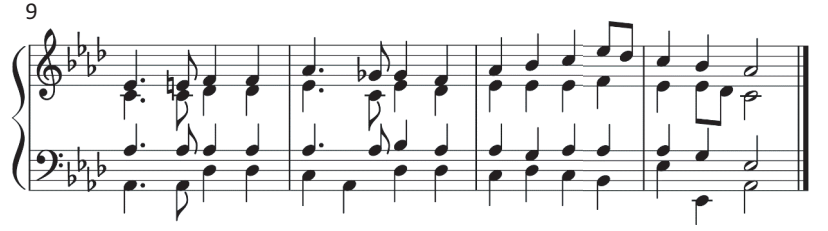

Source: August, K.T. (ed.), 2001, Chorale book of the Moravian Church in South Africa, The Moravian Church of South Africa, Genadendal

FIGURE 1: Tune $167 f$ 


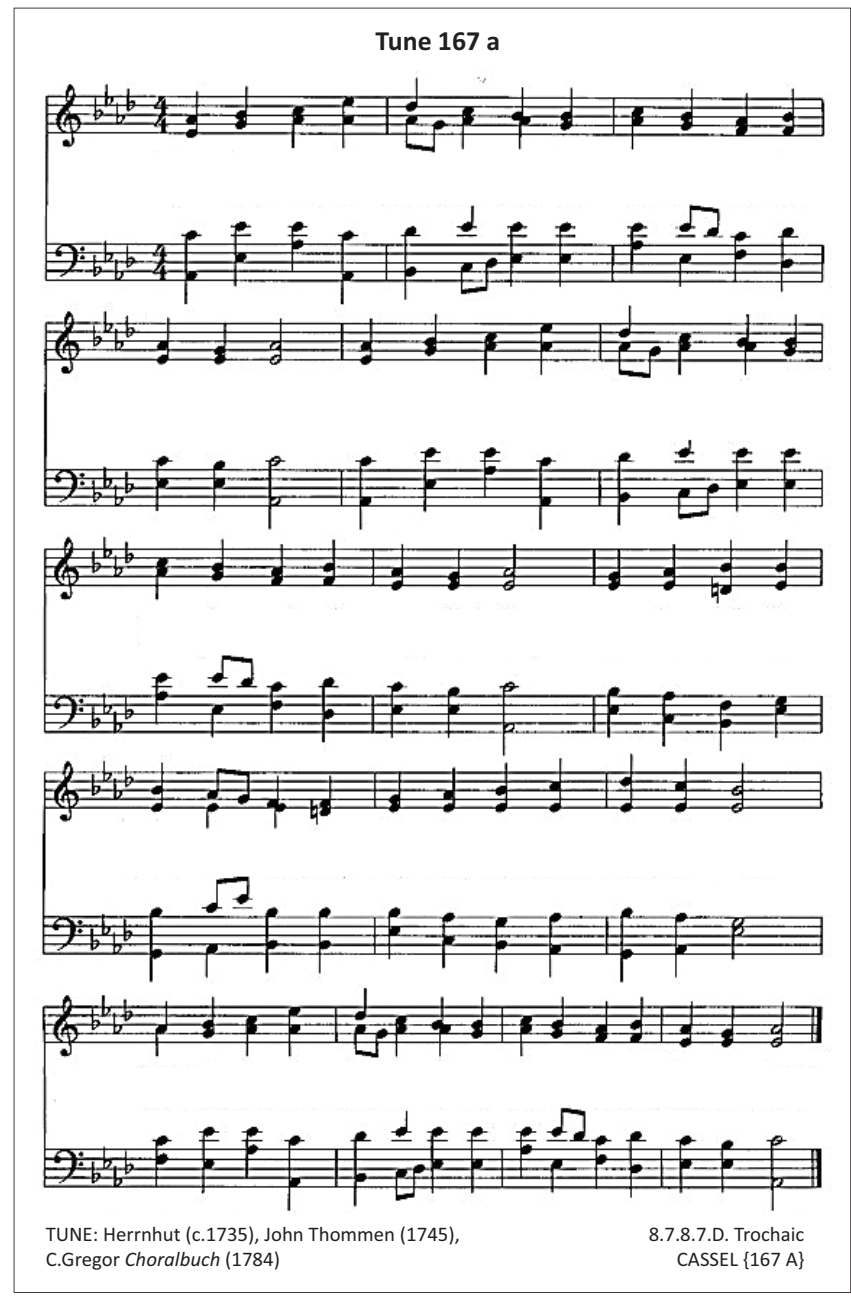

Source: August, K.T. (ed.), 2001, Chorale book of the Moravian Church in South Africa, The Moravian Church of South Africa, Genadendal

FIGURE 2: Tune 167a.

Jonathan Lawack (1943-) a contemporary South African composer, also worked on the revision of the Moravian hymnal in South Africa. He began his teaching career at the Moravian mission station, Clarkson in 1968, where he was also the choral conductor. Lawack had completed 2 years of teacher training at the Oudtshoorn Teachers Training College where music was part of the curriculum. He has over 40 years of choir training experience especially in primary school choirs and senior Moravian Church choirs.

After serving for 7 years as a teacher, he was promoted to the position of principal of a small Moravian school at Woodlands Primary School, where according to the Moravian tradition, music, and specifically the practise of Gemeinmusik, formed an integral part of teaching and education. After his stint at Woodlands, he went to teach at the Moravian Church school, Dr A.W. Habelgaarn Primary School, in Port Elizabeth, which later became a government school. Subsequently he returned to Clarkson as a principal, where music remained at the forefront of teaching and the children's choirs played an active role in religious activities such as at services and children's festivals. According to Lawack, senior choirs in the Moravian Church have long been central to church services and that was the way he was brought up and that was the way he started at the Clarkson Moravian mission station (J. Lawack pers. comm., 09 July 2014). These practises mirror the traditions of the Moravian Church from its earliest beginnings to the present and reveal the connectedness of Moravians.

In the interview, Lawack also retold an incident which had a profound influence on him. This incident occurred when Lawack was in standard 9 (grade 11) at Emil Weder High School in Genadendal. They practised under the baton of the late Rev. John Ulster (who later became a bishop of the church). Lawack was part of the hostel Moravian choir and they practiced in preparation for the inaugural service of the Strand Girls School when the lights suddenly went out and the Reverend was playing at that time. Lawack was so impressed by his ability just to keep on playing that he understood, at a tender age, that you need to know your work quite well to play like that. You need to read very well but you also need to know your music by heart and that has been part of his musical upbringing so to speak. To do well you need to practice and know your notes so that you can sing it by heart. This resonates with Zinzendorf's belief, as stated previously, that the congregation had to know the music by heart as it reflected their faith.

Lawack still believes in that and the incident made a huge impact on his upbringing as a music teacher. Rev. Ulster was one of the ministers in 1964 at Genadendal and he was the head of the boys' hostel and he assembled a choir from the girls' and boys' hostels, in preparation for the new Strand School for Girls. Rev. Ulster was a very accomplished organist and choir master. Lawack regards Rev. Ulster to have been one of the best organists and conductors he has ever met. Rev. Ulster's musicianship made a huge impact and impression on Lawack as a musician and choir master (pers. comm. Lawack, J. 09 July 2014). The new tune composed by Lawack, as shown in Figure 3, using the text from Schlicht's original hymn, as shown in Figure 4, is presented here (Laudate Dominum 1983):

What brought us together, what joined our hearts?

The pardon which Jesus, our Highpriest, imparts:

Tis this which cements the disciples of Christ,

who are into one by the Spirit baptized.

Text: Ludolf Ernst Schlicht (1714-1769)

The examples of hymns of two South African composers, Ulster and Lawack, are similar in musical style to the original versions of the hymn tunes. Both Daniel Ulster (1926-1986) and Jonathan Lawack (1948-) also display the concept of community in its broadest sense in the Moravian Church music, in so far as they have used the original texts, which are familiar to Moravians in South Africa and globally. It is a Moravian tradition not to compose new hymns tunes, and to use the original text; hence, the practise of the numbering of hymn tunes described previously. Both composers were active in establishing the Moravian hymnal of South Africa, and as practising Moravians would have been familiar with the tunes and traditions of this close-knit community of 


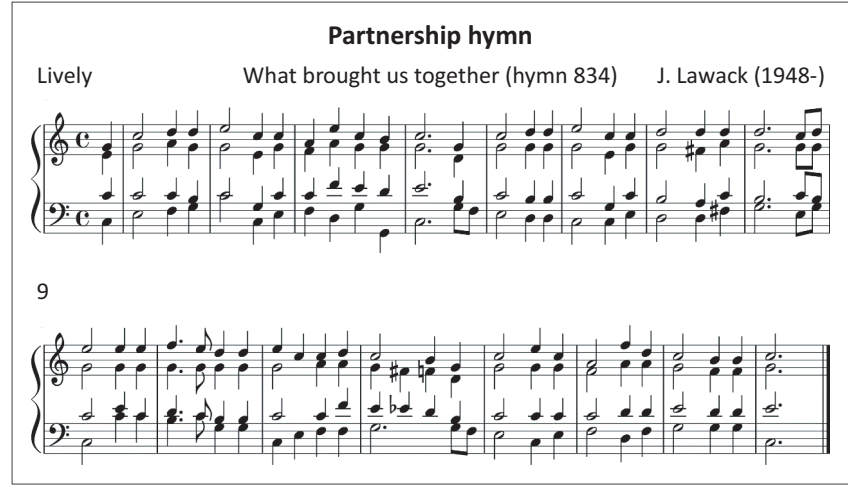

Source: J. Lawack personal manuscript copy

FIGURE 3: Partnership hymn: What brought us together (hymn 834).

practising Christians. Dan Ulster contributed to the Laudate hymnal of 1983, while Jonathan Lawack was actively involved with the revisions of the tune book in 1997.

The music of the Moravian Church in South Africa has enabled the promotion and development of the Moravian music culture. The Moravian communities have been cultural spaces where Moravian music and culture could be empowered and enhanced. Culture is passed down from one generation to the next through various and ever-widening channels (Kabagarama 1993:24). The Moravian Church music culture is passed down from one generation to the next in the congregational singing and the music unions of the Moravian Church in South Africa, namely, the MOCUSA and the BBSA. It is for these platforms that the composers under discussion composed their music. Moreover, both composers also attended Moravian schools where they participated in the traditions of singing hymns and preparing for church festivals and music festivals. They also learnt to play instruments and studied music at either university or college. Moravian music was furthermore entrenched when they themselves taught music at Moravian schools. Within the Moravian tradition, music making is linked to worship. When someone learns to play a musical instrument, they do so to fulfil a duty for the church by playing for services and special occasions. In this way, Moravians grow up with the rich treasure of Moravian chorales and hymns as well as the norms and values of the Moravian tradition.

The music that is composed then becomes part of the 'musicking' of the Moravian Church in South Africa. It can be said that the composers have composed their own cultural heritage. They are moreover linked to those who have gone before, in so far as they compose music for the general church year, for a four-part mixed choir to be accompanied by an organ (Reed Knouse 2008:97).

An analysis of the hymns shows that they are composed in the same style as the earlier hymns. The harmonisations are of such a nature that the congregation can sing the hymns $A$ Cappella in harmony but also by being accompanied by the brass band or alternatively, the organ. The texts for the hymns are written in Afrikaans, while the original text in German is acknowledged. The structure of the tunes is the same as that established by Grimm and Gregor. Reed Knouse (2008:51)

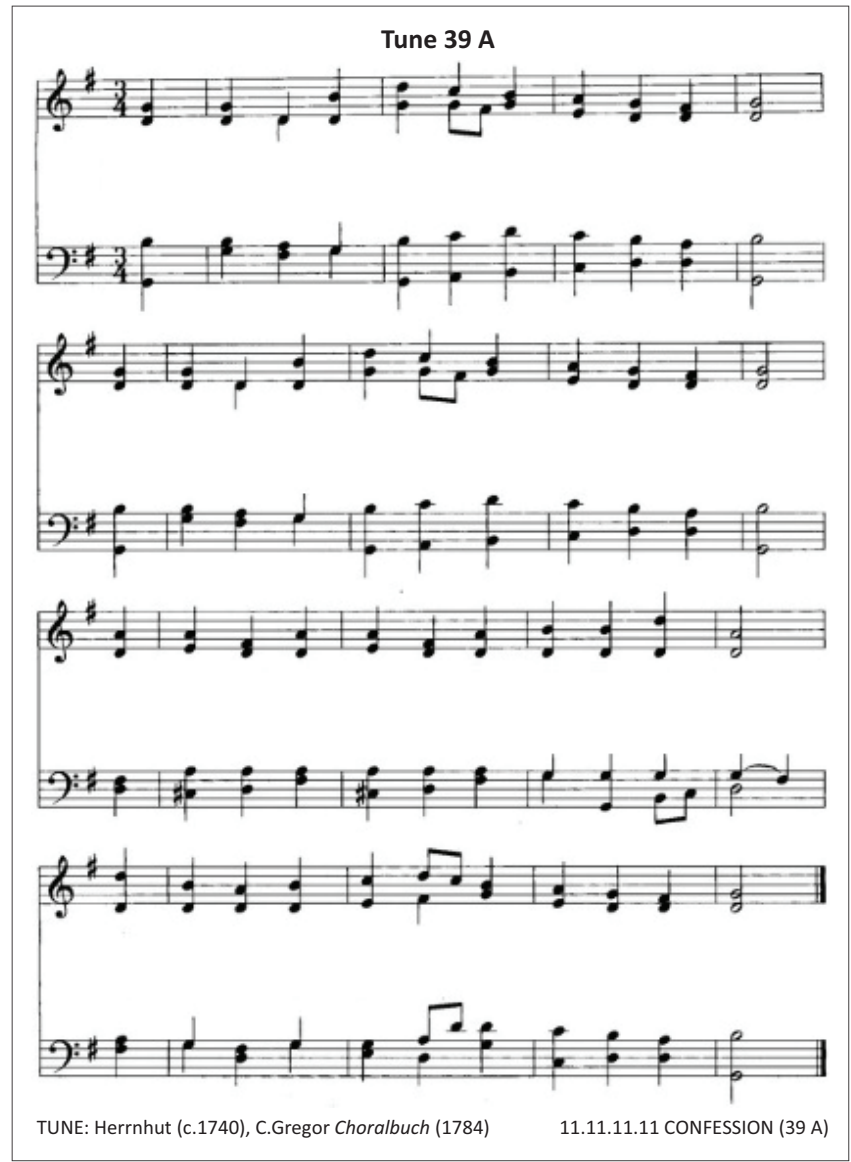

Source: Laudate Dominum 1983, Hymnal of the Moravian Church in South Africa, p. 39, Genadendal Printing Press, Genadendal

FIGURE 4: Tune $39 \mathrm{~A}$.

affirms that Moravian hymnody in other languages had specifically Moravian roots in this German tradition. Tunes with the same metrical structure are grouped together with the same number and distinguished from each other by an alphabet, as the examples in the article demonstrate. While neither of the South African composers discussed in this article composed many hymn texts, they did compose alternative hymn tunes as is the practice in the Moravian Church.

However, an analysis and comparison of their hymn tunes with the original tunes, that are still sung globally with many different instrumental arrangements, provide evidence of stylistic difference in their compositions. The original hymn tunes are composed in a simple, folk-like style, with easily singable melodies with mostly stepwise intervals and in manageable vocal ranges, which are also easily remembered; it is the music of the people. The ability for congregations to remember the tunes is furthermore aided by the clear patterns of form, with repetitions of melody and harmony. Both the original hymn tunes are 16 bars in length, with Zinzendorf's tune begins with a section of music (A) that is repeated (A); this is followed by a contrasting section of music (B) and then the first section is repeated (A); this can be shortened to AABA form. Schlicht's tune begins with a section of music (A) which is repeated; this is followed by a contrasting section (B), which in turn is followed by a completely different section, (C); This can be shortened as AABC form. 
Dan Ulster in his version of the tune, remains true to Zinzendorf's original tune. Both hymns are in the same key and meter and the first seven notes of Ulster's tune are directly borrowed from Zinzendorf, but with a different rhythmic pattern. Like Zinzendorf's melody, his also has 16 bars and is also easily singable, in a folk style. Ulster's hymn contrasts with Zinzendorf's tune in that it is in AABC form. This form is also common in Moravian hymns, as can be seen in the example from Schlicht.

In contrast to Ulster, Jonathan Lawack's hymn tune is in a completely different key and meter to the original tune although both hymns begin on an anacrusis to match the speech inflections and emphasis of speech patterns. While Schlicht's tune is in triple meter, Lawack's is in quadruple meter. The only similarity is that both utilise the same form. Schlicht's tune is in AABC form, and Lawack's tune is in a modified version, being in $\mathrm{AA}^{1} \mathrm{BC}$ form. The interview where Lawack spoke about composing was reminiscent of one that defines composers and their craft. This is evident in Lawack's composition because in true Moravian tradition he has used the original text, and while the melody follows a folk-like style, the range of his tune is very high. It appears to be more suited to a four-part choir, consisting of Soprano, Alto, Tenor and Bass (SATB) or an instrumental ensemble or a combination of both and in the authors' minds represents a composition for performance more so than for congregational singing.

Also, to be noted is the fact that Lawack belongs to a generation different from Ulster; Lawack is part of the new generation of Moravian composers, who having been initiated into and experienced Moravian tradition throughout their lives since childhood, are creating an oeuvre of hymn tunes that can be viewed as independent from the early Moravian tradition, while simultaneously paying homage to their rich tradition of hymnody.

\section{Conclusion}

The two Moravian hymns, under discussion, What brought us together? and Christian hearts in love united speak about Christian living in community here on the earth and in heaven. These Moravian hymn texts speak to the heart of Moravian theology and the tunes composed by the South African composers for these two hymns show the South African Moravian hymnody identity that continues the Moravian heritage of composing new tunes to existing texts. In this article, we see how these composers played active roles in developing the Moravian hymnody heritage in their respective Moravian communities and by their example have paved the path for other composers in the Moravian community.

\section{Acknowledgements}

The authors would like to thank the Suid-Afrikaanse Kerkorrel Vereniging (SAKOV) and Culture, Art, Tourism,
Hospitality and Sport Sector Education and Training Authority (CATHSSETA) for financial support in conducting this study as they provided bursaries for the $\mathrm{PhD}$ study on which the article is based.

\section{Competing interests}

This research received no specific grant from any funding agency in the public, commercial or not-for-profit sectors.

\section{Authors' contributions}

D.B. contributed $80 \%$ of the work. His supervisor for his doctoral study, A.C.V., contributed $20 \%$. This study is based on D.B.'s PhD thesis.

\section{Ethical consideration}

\section{H/13/ART/MUS-002.}

\section{Funding information}

SAKOV travel bursary was used to visit the Moravian community in Pennsylvania, USA, and the CATHSSETA doctoral bursary funded the doctoral study.

\section{Data availability statement}

Data sharing is not applicable to this article as no new data were created or analysed in this study.

\section{Disclaimer}

The views and opinions expressed in this article are those of the authors and do not necessarily reflect the official policy or position of any affiliated agency of the authors.

\section{References}

Akrofi, E., Smit, M. \& Thorsén, S., (eds.), 2007, Music \& identity: Transformation \& negotiation, African Sun Media, Stellenbosch.

Anon, 1983, Laudate, s.n., Genadendal.

August, K.T. (ed.), 2001, Chorale book of the Moravian Church in South Africa, The Moravian Church of South Africa, Genadendal.

Bradshaw, P. (ed.), 2002, The new SCM dictionary of liturgy and worship, SCM Press, London.

Boyce-Tillman, J., 2016, Experience music: Restoring the spiritual: Music as well-being, Peter Lang, Oxford.

Caldwell, A., 2007, 'Moravian music on a mission', The Hinge: A Journal of Christian Thought for the Moravian Church 14(1), 4-30.

De Wet, T., Teugels, J.L. \& Van Deventer, P., 2014, 'Historic bells in Moravian missions in South Africa's Western Cape', Historia 59(2), 94-119.

Freeman, A.J., 1998, An ecumenical theology of the heart: The theology of count Nicholas Ludwig von Zinzendorf, Moravian Church in America, s.l.

Fries, A., 2003, Customs and practices of the Moravian Church, Moravian Church in America, s.l.

Gordon, D., 1927, Letters from the Cape, Oxford University Press, London.

Hall, H.H., 1981, 'Music education in America, ca. 1750 to ca. 1830', Journal of Research in Music Education 29(3), 225-234. https://doi.org/10.2307/ 3344996

Hymnary.org, n.d., Christian Hearts in Love United, viewed 05 November 2018, from https://hymnary.org/text/christian_hearts_in_love_united.

Ife, J., 2013, Community development in an uncertain world, Cambridge University Press, Cape Town.

Jooste, S.J., 1992, 'Die Bydrae van Duitse Musici tot die Musieklewe in Suid-Afrika in die Negentiende Eeu', Suid-Afrikaanse Tydskrif Kulltuurgeskeidenis 6(4), 150-159. 
Kabagarama, D., 1993, Breaking the ice: A guide to understanding people from other cultures, Allyn \& Bacon, Boston, MA.

Koraalboek vir Psalms en Gesange 1978, N.G. Kerk-uitgewers, Kaapstad.

Krüger, B. \& Schaberg, P.W., 1984, The pear tree bears fruit, Genadendal Printing Press, Genadendal.

Kunhiyop, S.W., 2012, African Christian theology, Zondervan, Grand Rapids, MI.

Laudate Dominum 1983, Hymnal of the Moravian Church in South Africa, Genadendal Printing Press, Genadendal.

Lewis, A.J., 1962, Zinzendorf, the Ecumenical Pioneer: A study in the Moravian contribution to Christian mission and unity, Westminster, Philadelphia, PA.

Lonas, H., 1890, Choralbuch der evangelischen Brüdergemeine, n.p., n.p.

Meskell, L., 2012, The nature of heritage: The new South Africa, Wiley-Blackwell, Oxford.

Morgan, S. \& Boyce-Tillman, J., 2016, A river rather than a road: The Community Choir as spiritual experience, Peter Lang, Oxford.

Pickel, B., 1997, Coloured ethnicity and identity: A case study in the former coloured areas in the Western Cape/South Africa, Lit Verlag, Hamburg.

Reed Knouse, N. (ed.), 2008, The music of the Moravian Church in America, University of Rochester Press, Rochester, NY.
Reichelt, G. \& De Schweinitz, B., 1886, 'The literary works of the foreign missionaries of the Moravian Church', Transactions of the Moravian Historical Society 2(9), 377-395, viewed 03 June 2019, from http://www.jstor.org/ stable/41179756

Robinson, L.A., 2014, 'New leaves on old trees: A synthesis of early American Church Music through contemporary composition', Unpublished thesis, South-Eastern University, Lakeland, FL.

Settari, O., 1984, Jan Amos Comenius - A Czech hymnographist, music theorist and educationist, viewed 01 June 2019, from digilib.phil.muni.cz/bitstream/handle/ 11222.digilib/112230/H_Musicologica_19-1984-1_10.pdf

Small, C., 1998, Musicking: The meanings of performing and listening, Wesleyan University Press, Hanover

Traupman-Carr, C., 2000, 'Pleasing for our use': David Tannenberg and the organs of the Moravians, Lehigh Press, Bethlehem.

University of Cambridge, n.d., Department of Archaeology, viewed 11 October 2018, from https://www.arch.cam.ac.uk/abut-us/heritage

Weinlick, J., 2001, Count Zinzendorf. The story of his life and leadership in the renewed Moravian Church, The Moravian Church in North America, Bethlehem, PA.

Weinlick, J. \& Frank, A., 2010, The Moravian Church through the ages: The story of a worldwide, pre-reformation Protestant Church, Rev. edn., The Moravian Church in North America, Bethlehem, PA. 